\title{
Renin inhibition with aliskiren in hypertension: focus on aliskiren/hydrochlorothiazide combination therapy
}

\author{
Kalathil K Sureshkumar \\ Division of Nephrology \\ and Hypertension, Allegheny \\ General Hospital, Pittsburgh, \\ Pennsylvania, USA
}

Correspondence: Kalathil K Sureshkumar Division of Nephrology and Hypertension, Allegheny General Hospital, Pittsburgh, Pennsylvania I52I2, USA

$\mathrm{Tel}+\mathrm{I} 4123593319$

Fax + I 4I23594I36

Email ksureshk@wpahs.org

\begin{abstract}
Hypertension is a major risk factor for the development of cardiovascular and renal disease. The incidence of hypertension is increasing globally and the rate of blood pressure control remains inadequate. Renin-angiotensin-aldosterone system (RAAS) plays a crucial role in volume regulation and maintenance of blood pressure. Pathological activation of RAAS results in chronic hypertension and consequent end organ damage. Most patients with hypertension require combination therapy using agents with complimentary mechanisms of action. Hydrochlorothiazide (HCTZ) together with an agent blocking the RAAS such as an angiotensin converting enzyme (ACE) inhibitor or angiotensin receptor blocker (ARB) are widely used effective anti-hypertensive therapy. Aliskiren is an orally effective direct renin inhibitor that blocks the generation of angiotensin I from angiotensinogen, the rate limiting step of RAAS activation. Studies have shown equivalent antihypertensive efficacy of aliskiren when compared to existing medications such as HCTZ, ACE inhibitors and ARBs. Aliskiren has also been tested in combination therapies. The current review aims to look at the efficacy of aliskiren therapy in hypertension and the evidence for using aliskiren in combination with HCTZ.
\end{abstract}

Keywords: hypertension, renin-angiotensin-aldosterone system, aliskiren, aliskirenhydrochlorothiazide, combination therapy, renin inhibitors

\section{Introduction}

Elevated blood pressure (BP) is a major risk factor for the development of myocardial infarction, heart failure, stroke and renal failure. Greater than $25 \%$ of the global population was hypertensive in 2000 with a $60 \%$ projected increase in incidence by the year 2025 (Kearney et al 2005). Approximately 30\% of the US population is hypertensive (Ong et al 2007). According to the 7th Joint National Committee on the prevention, detection, evaluation and treatment of high blood pressure (JNC-7), only about a third of treated US adult patients have their BP adequately controlled (Chobanian et al 2003). An epidemiology study of hypertension treatment and control in five European countries, Canada and the US showed lower treatment and control rates in Europe when compared to North America (Wolf-Maier et al 2004).

Hypertension is a treatable disease and effective medical therapies have been available for nearly 5 decades. Socio-economic conditions, treatment non-compliance and inadequate prevention strategies have all been implicated as barriers to adequate BP control. The major pharmacological strategies currently utilized for hypertension management include volume control with diuretics, suppression of central and peripheral sympathetic nervous system activity, vasodilation with ion channel manipulation and blockade of renin-angiotensin-aldosterone system (RAAS). Monotherapy results in adequate control of BP only in fewer that $50 \%$ of patients (Materson et al 1993; Cushman et al 2002; Chobanian et al 2003). Most patients require combination 
therapy using agents with complimentary mechanisms of action. Life style modification should also be an integral part of the treatment plan. Combination therapy may enable the utilization of sub-maximal doses of component drugs thus minimizing adverse events without significantly affecting potency. Several combination agents are currently available. The most widely used combinations involve a thiazide diuretic like hydrochlorothiazide (HCTZ) together with a drug blocking the RAAS such as angiotensin converting enzyme (ACE) inhibitor or angiotensin receptor blocker (ARB). RAAS has long been known to play a crucial role in both the regulation of $\mathrm{BP}$ as well as atherogenesis and vascular damage (Oparil and Haber 1974; Dzau 2001). Thiazide diuretics block the uptake of $\mathrm{Na}^{+}$in the distal convoluted tubule of the nephron resulting in salt and water depletion. While this can lower the BP, the resulting activation of the RAAS may limit the antihypertensive benefits of diuretics. Thus drugs that inhibit the RAAS such as ACE inhibitors and ARBs are considered attractive for combination with thiazide diuretics (Skolnik et al 2000; Waeber B 2003). Recently, a direct renin inhibitor namely aliskiren was approved by the US Food and Drug Administration and the European regulatory agency for the treatment of hypertension. The antihypertensive efficacy of aliskiren has been studied both as monotherapy and in combination with other agents including HCTZ. The current review includes an overview of RAAS and the clinical experience of renin blockade with aliskiren in hypertension with particular focus on the evidence for using aliskiren/HCTZ combination. Articles published in English language pertaining to aliskiren were reviewed.

\section{Renin-angiotensin-aldosterone system and its blockade}

A schematic of the RAAS is depicted in Figure 1. Renin is an aspartic protease generated and released from the juxtaglomerular cells in the kidney. The renin molecule has two homologous lobes and the cleft between the lobes contain the active site (Danser and Deinum 2005). Under the influence of renin, angiotensinogen, the only know substrate of renin is cleaved to generate the decapeptide angiotensin I (Ang I). This is the rate-limiting step of RAAS activation. In the presence of angiotensin converting enzyme (ACE), Ang I is converted into the octapeptide hormone angiotensin II (Ang II), a powerful vasoconstrictor that mediates its activity through the type- 1 angiotensin II ( $\left.\mathrm{AT}_{1}\right)$ receptor. Binding of Ang II to $\mathrm{AT}_{1}$ receptor increases $\mathrm{BP}$, and promotes aldosterone secretion from adrenal cortex, sodium reabsorption in renal proximal tubules, and catecholamine release from pre-synaptic nerve endings and adrenal medulla (Kim and Iwao 2000). Pathological activation of RAAS can result in hypertension with consequent end-organ damage.

Several medications can interrupt the RAAS cascade but redundant pathways limit drug effects. Beta blockers inhibit renin secretion from the juxtaglomerular cells. ACE inhibitors block the conversion of Ang I to Ang II but non-ACE pathways of Ang II generation such as chymase and dipeptidases present in end organs including heart, kidney and blood vessels get activated under conditions of ACE inhibition (Hollenberg et al 1998; Urata et al 1990). ACE inhibitors are not specific for RAAS and can prevent ACE-induced inactivation of bradykinin and substance $\mathrm{P}$ that are thought to be responsible for ACE-inhibitor related side effects such as cough and angioedema. ARBs exert their effect by blocking $\mathrm{AT}_{1}$ receptors activation by Ang II. This may lead to unopposed stimulation of other types of receptors such as type-2 and type-4 Ang II receptors ( $\mathrm{AT}_{2}$ and $\mathrm{AT}_{4}$ receptors). Physiological role of these receptors are not clear but may be important for endothelial function (Wantanabe et al 2005). Over stimulation of $\mathrm{AT}_{2}$ receptors can generate deleterious agents such as oxygen free radicals, pro-inflammatory cytokines and pro-fibrotic mediators and may promote left ventricular hypertrophy (Williams 2001; Azizi et al 2006). On the other hand, beneficial effects such as inhibition of renin synthesis and Ang II formation are also reported following $\mathrm{AT}_{2}$ receptor activation (Siragy et al 2005). Both ACE inhibitors and ARBs stimulate renal renin production by disrupting the inhibitory feed back of Ang II on juxtaglomerular cells. The resulting increase in renin eventually restores Ang II level.

As mentioned before, the rate limiting step in RAAS is the conversion of angiotensinogen to Ang I under the influence of renin. There is a steep step down in concentration from angiotensinogen to Ang I which makes renin inhibition an attractive option for effective RAAS blockade. Animal studies using gene-dosing strategies showed increase in BP in the presence of increased copies of angiotensinogen gene but not with ACE gene, underscoring the rationale for blocking the conversion of angiotensinogen to Ang I (Smithies 1997). Even though renin was discovered more than a century ago, a successful direct renin inhibitor has been available for clinical use only recently. Investigational renin inhibitors such as remikiren, enalkiren, ditekiren and zanikern developed in the past were limited by short half-life, high costs, and poor bioavailability (Fisher and Hollenberg 2001). 


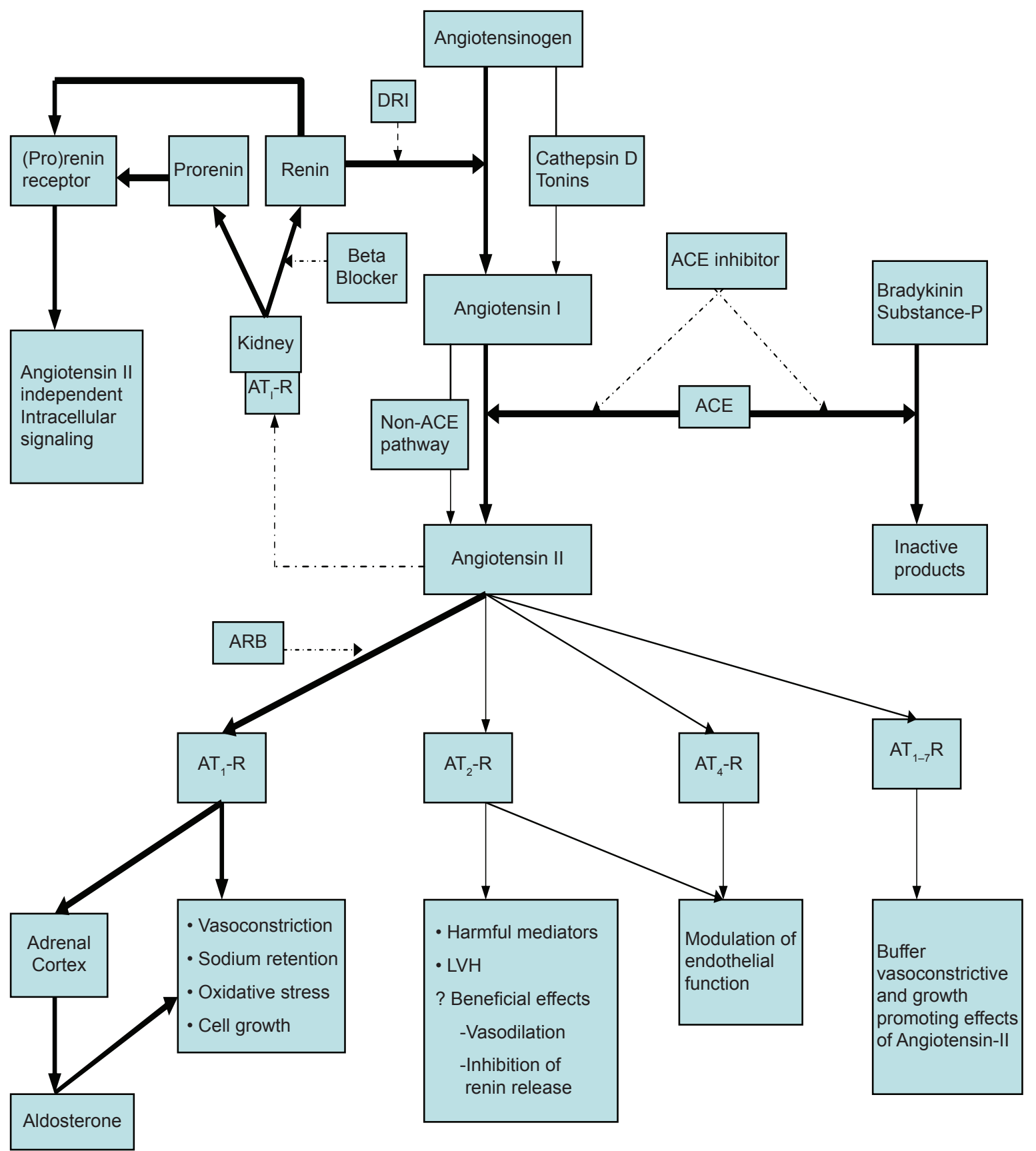

Figure I Renin-angiotensin-aldosterone system and the sites of blockade. Thick arrows indicate main pathways, thin arrows denote alternative pathways and dashed arrows show sites of blockade.

Abbreviations: ACE, angiotensin converting enzyme; ARB, angiotensin receptor blocker; AT-R, angiotensin receptor; DRI, direct renin inhibitor; LVH, left ventricular hypertrophy.

Aliskiren is the first direct renin inhibitor with sufficient bioavailability $(2.5 \%)$, safety and efficacy that was tested in human studies.

Pro-renin is an inactive precursor of renin that is constitutively released from the kidney. Pro-renin is rendered inactive by a 43 -amino acid $\mathrm{N}$-terminus that covers the enzymatic cleft. The circulating level of pro-renin is approximately 10-fold higher than renin levels and the proportion is increased in diabetics (Luetscher et al 1985; Danser et al 1998). Increased pro-renin levels may predict the onset of microalbuminuria in patients with diabetes (Chiarelli et al 2001). Pro-renin can undergo proteolytic and nonproteolytic activation. Proteolytic activation occurs predominantly in the juxtaglomerular cells. Nonproteolytic activation can be induced by exposure to low temperature and low $\mathrm{pH}$ as well as through binding to the recently discovered (pro)renin 
receptor (Nguyen et al 2002). (Pro)renin receptors have been localized to mesangial cells, distal collecting tubular cells of kidney, vascular smooth muscle cells, human heart and brain. These receptors bind both renin and pro-renin. Once bound to (pro)renin receptors, activated pro-renin and renin facilitate circulation independent Ang I production locally. The binding also promote intracellular signaling pathways in an angiotensin independent manner through mitogen-activated protein kinases leading to upregulation of pro-fibrotic mediators with harmful end-organ consequences that are inhibited by neither ACE inhibitors nor ARBs. (Pro)renin receptor blockade inhibited progression of nephropathy and reversed glomerulosclerosis in rats with streptozotozin- induced diabetes with proteinuria and glomerulosclerosis (Takahashi et al 2007).

\section{Aliskiren: pharmacokinetic and pharmacodynamic properties}

Aliskiren is a small-molecular-weight, orally active, non-peptide direct renin inhibitor with very high affinity and specificity for human renin (Wood et al 2003). It blinds to the S1/S3 pocket at the active site of renin molecule thus preventing the conversion of angiotensinogen to Ang I. Aliskiren is a potent inhibitor of renin with an $\mathrm{IC}_{50}$ (concentration inhibiting $50 \%$ of activity) of $0.6 \mathrm{nmol} / \mathrm{L}$. Renin is measured as plasma renin concentration (PRC) and plasma renin activity (PRA). PRC measures the actual amount of renin in plasma regardless of its enzymatic activity and is expressed as either $\mu \mathrm{U} / \mathrm{mL}$ or $\mathrm{pg} / \mathrm{mL}$. PRA denotes the enzymatic activity of renin and is measured as the rate of angiotensin I production after adding serum to angiotensinogen. PRA is expressed as $\mathrm{ng} / \mathrm{ml} /$ hour.

Effects of various medications on RAAS pathway are shown in Table 1. With the exception of beta blockers, all other agents blocking RAAS and diuretics including HCTZ increase PRC. Aliskiren and ACE inhibitors achieve this by decreasing Ang II levels and ARBs by blocking inhibitory effects of Ang II on AT, receptors on juxtaglomerular cells. Diuretics increase PRC by inducing volume depletion. The magnitude of PRC elevation is more pronounced when aliskiren is combined with HCTZ. PRA is increased by ACE inhibitors, ARBs and HCTZ while aliskiren use alone and in combination with HCTZ is associated with a decrease in PRA. Other agents that can decrease PRA include beta blockers and central $\alpha-2$ receptor agonists.

\section{Pharmacokinetic properties}

Pharmacokinetic properties of aliskiren have been reported before (Azizi et al 2006; Novartis Pharmaceuticals Corporation 2007; Waldmeier et al 2007). After an oral dose, the bioavailability of aliskiren is $2.5 \%$. High aqueous solubility and affinity for renin compensates for the low absolute bioavailability of aliskiren. Peak plasma concentration is achieved within one to three hours following a single oral dose. Plasma concentration increased in a dose dependent manner at dose ranges of 40 to $640 \mathrm{mg} /$ day. Steady state blood levels are reached in about 7 to 8 days. A terminal half-life of 23 to 36 hours makes the drug suitable for once daily administration (Azizi et al 2006). A dose-dependent increase in trough plasma concentration of aliskiren from 2.6 to $30.0 \mathrm{ng} / \mathrm{mL}$ was seen with aliskiren doses ranging from 37.5 to $300 \mathrm{mg}$ /day in one study (Stanton et al 2003). Mean trough plasma concentrations of aliskiren were $10.7 \pm 6.7,13.1 \pm 8.3,9.5 \pm 5.9$ and $7.6 \pm 3.2 \mathrm{ng} / \mathrm{mL}$ respectively in hypertensive patients taking aliskiren $150 \mathrm{mg}$, aliskiren/HCTZ 150/25 mg, ramipril/ aliskiren 5/150 mg and irbesartan aliskiren 150/150 mg daily in another study (O'Brien et al 2006).

Aliskiren has a large volume of distribution and a plasma protein binding of $49.5 \%$. Mean area under the curve (AUC) and $\mathrm{C}_{\max }$ of aliskiren decreased by $71 \%$ and $85 \%$ respectively when taken with a high fat meal (Novartis Pharmaceuticals Corporation 2007). Patients should take aliskiren on an

Table I Medication effects on RAAS pathway

\begin{tabular}{llllllll}
\hline Medication & PRC & PRA & Angiotensinogen & Ang I & Ang II & Ang I-7 & Aldosterone \\
\hline B-Blocker & $\downarrow$ & $\downarrow$ & - & $\downarrow$ & $\downarrow$ & $\downarrow$ & $\downarrow$ \\
ACE-I & $\uparrow$ & $\uparrow$ & $\downarrow$ & $\uparrow$ & $\downarrow$ & $\uparrow$ & $\downarrow$ \\
ARB & $\uparrow$ & $\uparrow$ & $\downarrow$ & $\uparrow$ & $\uparrow$ & $\uparrow$ & $\downarrow$ \\
Aliskiren & $\uparrow \uparrow$ & $\downarrow \downarrow$ & - & $\downarrow$ & $\downarrow$ & $\downarrow$ & $\downarrow$ \\
HCTZ & $\uparrow$ & $\uparrow$ & $\downarrow$ & $\uparrow$ & $\uparrow$ & $\uparrow$ & - \\
Aliskiren/HCTZ combination & $\uparrow \uparrow \uparrow$ & $\downarrow$ & - & - & - & - & - \\
\hline
\end{tabular}

Abbreviations: ACE-I, angiotensin converting enzyme inhibitor; Ang I, angiotensin I; Ang II, angiotensin II; Ang I-7, angiotensin I-7; ARB, angiotensin receptor blocker; HCTZ, hydrochlorothiazide; PRA, plasma renin activity; PRC, plasma renin concentration; $\uparrow$, increased; $\downarrow$, decreased; -, unchanged or unknown. 
empty stomach and establish a routine pattern with regard to meals. A $32 \%$ to $70 \%$ inter-subject variability in AUC and $\mathrm{C}_{\max }$ was noted for a 40 to $1800 \mathrm{mg}$ dose range of oral aliskiren (Nussberger et al 2002). AUC and $\mathrm{C}_{\max }$ were higher by $28 \%$ and $57 \%$ respectively in subjects over 65 years compared to those 18 to 45 years old (Vaidyanathan et al 2007). Following the administration of $300 \mathrm{mg}$ aliskiren in healthy subjects, $90.9 \%$ drug elimination was via the fecal route and only $0.6 \%$ was recovered from urine (Waldmeier et al 2007). Hepatic first-pass effect is minimal for aliskiren and modification of starting dose is not recommended in patients with hepatic and renal impairment. Pharmacokinetics of aliskiren are similar among Japanese, Blacks and Caucasians.

Aliskiren is not metabolized by cytochrome P450 system and has a low potential for drug interactions. The pharmacokinetics of amlodipine, valsartan, HCTZ and ramipril were not influenced by co-administration with aliskiren in healthy volunteers (Vaidyanathan et al 2006). Co-administration of lovastatin, atenolol, celecoxib and cimetidine did not significantly change AUC and therapeutic half-life of aliskiren (Dieterle et al 2005). Aliskiren did not exert detectable effects on the pharmacokinetics and pharmacodynamics of warfarin (Dieterle et al 2004). There were no clinically significant interactions between aliskiren and digoxin in health volunteers (Dieterich et al 2006). Co-administration of aliskiren with furosemide reduced the $\mathrm{AUC}$ and $\mathrm{C}_{\max }$ of furosemide by $30 \%$ and $50 \%$ respectively (Novartis Pharmaceuticals Corporation 2007).

\section{Pharmacodynamic properties}

Since renin is very species specific, animal testing of human renin inhibitors are limited to marmosets and guinea pigs. Aliskiren doses of 1 and $3 \mathrm{mg} / \mathrm{kg}$ completely suppressed PRA for 6 and 12 hours respectively in sodium depleted marmosets (Wood et al 2005). BP lowering effects of aliskiren were similar to valsartan and benzapril. Aliskiren decreased PRA, Ang I and Ang II levels in normotensive volunteers in a dose dependent manner but caused a 10-fold increase in PRC (Nussberger et al 2002). A decrease in plasma and urine aldosterone levels were also noted with daily aliskiren doses of $80 \mathrm{mg}$ and above. Aliskiren $160 \mathrm{mg}$ and enalapril $20 \mathrm{mg}$ doses were comparable in terms of their inhibitory effects on Ang II levels (Nussberger et al 2002).

A small randomized four-period cross-over study looked at the effects of single doses of aliskiren $300 \mathrm{mg}$, valsartan $160 \mathrm{mg}$ and aliskiren/valsartan 150/80 mg combination in 12 mildly sodium-depleted volunteers (Azizi et al 2004).
Aliskiren lowered PRA, and plasma levels of Ang I and Ang II for 48 hours, stimulated active renin release more strongly than valsartan $160 \mathrm{mg}$ and decreased urinary aldosterone excretion for longer duration than valsartan $160 \mathrm{mg}$. The effects of aliskiren/valsartan 150/80 mg were similar to aliskiren $300 \mathrm{mg}$ but greater than those of valsartan $160 \mathrm{mg}$. Aliskiren blunted the valsartan-induced rise in PRA and plasma levels of Ang I and Ang II. Similar findings were also reported in sodium-replete normotensive individuals (Azizi et al 2007).

\section{Preclinical target organ protection studies of aliskiren}

Since renin is highly species specific and aliskiren inhibits only primate renin, usual animal models of hypertension studies can not be used to test the end organ effects of aliskiren. Double transgenic rats (dTGR) which carries human genes for both renin and angiotensin were developed to circumvent this issue (Ganten et al 1992; Fukamizu et al 1993). These dTGR can generate large amounts of Ang II and untreated animals die by 8 weeks from cardiac dysfunction and renal failure. This feature makes dTGR an excellent model to test the effects of human renin inhibitors.

The target organ protection by aliskiren and valsartan were compared in dTGR (Pilz et al 2005). Matched dTGR received no treatment, aliskiren ( 0.3 or $3 \mathrm{mg} / \mathrm{kg} / \mathrm{day})$ or valsartan (1 or $10 \mathrm{mg} / \mathrm{kg} /$ day) from weeks 6 to 9 . All groups had hypertension at week 6. Untreated dTGR developed worsening hypertension, increased creatinine and albuminuria by week 7 with $100 \%$ mortality by week 9 . Both aliskiren treated groups and high-dose valsartan treated group had lower BP and albuminuria and normal serum creatinine levels by weeks 9 with $100 \%$ survival. Mortality was $26 \%$ in low-dose valsartan group and this group also had ventricular hypertrophy and diastolic dysfunction. In this model, renin inhibition had more favorable effect on end organ damage compared to angiotensin receptor blockade. In another study of dTGR model, both aliskiren and losartan reduced albuminuria and renal expression of inflammatory markers (Shagdarsuren et al 2005). Similar findings with reduction of albuminuria and reduced gene expression of TGF-beta and collagen III and IV were observed with aliskiren use in dTGR with diabetic nephropathy (Kelly et al 2007).

The role of renin inhibition and $\mathrm{AT}_{1}$-receptor blockade in attenuating cardiac oxidative stress and cellular remodeling was evaluated in the transgenic TG(mRen2)27 rat, a rodent model of chronically elevated tissue Ang II levels with consequent hypertension, insulin resistance and cardiovascular 
damage (Whaley-Connell et al 2008). Administration of aliskiren and irbesartan were both associated with significant attenuation of cardiac functional and structural alterations in TG (mRen2)27 rats but irbesartan caused greater reductions in BP and markers of oxidative stress. In another study, aliskiren use lowered BP, prevented albuminuria and suppressed renal expressions of TGF-beta and collagen I in streptozotozin-diabetic TG (mRen2)27 rats (Feldman et al 2008). Aliskiren also reduced renal expression of (pro)renin receptor.

\section{Clinical efficacy of aliskiren in hypertension}

Aliskiren has been evaluated as both monotherapy and in combination therapy in the treatment of hypertension. Table 2 outlines the studies of aliskiren in hypertension.

\section{Aliskiren monotherapy in hypertension}

Clinical trials have compared the antihypertensive efficacy of aliskiren with placebo, HCTZ, ARBs, ACE inhibitors and calcium channel blockers. The antihypertensive effect of aliskiren was evaluated in 455 Japanese patients with a mean sitting diastolic BP (msDBP) of 95 to $110 \mathrm{mmHg}$ (Kushiro et al 2006). Patients were assigned to aliskiren $75 \mathrm{mg}, 150 \mathrm{mg}$ or $300 \mathrm{mg}$ or placebo for 8 weeks in a double-blind randomized manner. Aliskiren produced a dose dependent-reduction in both msDBP ( $p<0.0005$ vs placebo for each dose) and mean sitting systolic BP (msSBP) $(\mathrm{p}<0.001$ vs placebo for each dose). Placebo corrected reductions in $\mathrm{msSBP} / \mathrm{msDBP}$ were 5.7/4.0, 5.9/4.5 and 11.2/7.5 $\mathrm{mmHg}$ for aliskiren doses of 75, 150 and $300 \mathrm{mg}$ respectively. At the study end, $27.8 \%, 47.8 \%, 48.2 \%$ and $63.7 \%$ of patients in the placebo and aliskiren 75, 150 and $300 \mathrm{mg}$ groups, respectively had a successful response (defined as a DBP $<90 \mathrm{mmHg}$ and/ or $\geq 10 \mathrm{mmHg}$ reduction from baseline, $\mathrm{p}<0.005 \mathrm{vs}$ placebo for each aliskiren dose). However it should be noted that only about $36 \%$ of patients showed adequate response to $300 \mathrm{mg}$ aliskiren monotherapy when corrected for the placebo effect. Aliskiren demonstrated placebo-like tolerability. In another study, 672 patients with msDBP of 95 to $109 \mathrm{mmHg}$ were randomized to aliskiren doses of $150 \mathrm{mg}, 300 \mathrm{mg}, 600 \mathrm{mg}$ or placebo for 8 weeks (Oh et al 2007). Compared to a reduction in $\mathrm{msSBP} / \mathrm{msDBP}$ of $3.8 / 4.9 \mathrm{mmHg}$ with placebo, aliskiren doses of $150 \mathrm{mg}, 300 \mathrm{mg}$ and $600 \mathrm{mg}$ resulted in 13.0/10.3, 14.7/11.1 and 15.8/12.5 $\mathrm{mmHg}$ reductions respectively ( $\mathrm{p}<0.0001)$. Aliskiren doses of $150 \mathrm{mg}, 300 \mathrm{mg}$ and $600 \mathrm{mg}$ resulted in PRA reductions of $79.5 \%, 81.1 \%$ and $75.0 \%$ from baseline but PRC increased by $51.5 \%, 101.6 \%$ and $228.5 \%$ from the baseline. Patients taking $600 \mathrm{mg}$ of aliskiren reported increased incidence of diarrhea.

In a multi-center double-blind trial, 652 patients with mild to moderate hypertension were randomized to once-daily doses of aliskiren (150 mg, $300 \mathrm{mg}$ or $600 \mathrm{mg}$ ) irbesartan $150 \mathrm{mg}$ or placebo for 8 weeks (Gradman et al 2005). Compared to placebo, all doses of aliskiren significantly lowered trough msSBP and msDBP $(\mathrm{p}<0.001)$ (Table 2). The dose-response curve for aliskiren showed a plateau at $300 \mathrm{mg}$ and antihypertensive efficacy was similar between aliskiren $150 \mathrm{mg}$ and irbesartan $150 \mathrm{mg}$. BP control (defined as a $\mathrm{BP}<140 / 90 \mathrm{mmHg}$ ) was achieved in 37.8\%, 50\% and $20.8 \%$ of patients on aliskiren $150 \mathrm{mg}, 300 \mathrm{mg}$ and placebo. Aliskiren was well tolerated.

Another double-blind trial randomized 226 patients with mild to moderate hypertension to four doses of aliskiren (37.5 mg, $75 \mathrm{mg}, 150 \mathrm{mg}, 300 \mathrm{mg}$ ) or losartan $100 \mathrm{mg}$ daily for 4 weeks (Stanton et al 2003). The mean \pm SD changes in daytime ambulatory systolic BP were $-0.4 \pm 11.7$, $-5.3 \pm 11.3,-8.0 \pm 11.0$ and $-11.0 \pm 11.0 \mathrm{mmHg}$ respectively in patients receiving $37.5 \mathrm{mg}, 75 \mathrm{mg}, 150 \mathrm{mg}$ and $300 \mathrm{mg}$ doses of aliskiren $(\mathrm{p}=0.0002)$. The changes in PRA (median change as percentage with inter- quartile range) for the same doses of aliskiren were $-55(-64,-11),-60$ $(-82,-46),-77(-86,-72)$ and $-83(-92,-71)$ respectively $(\mathrm{p}=0.0008)$. Losartan $100 \mathrm{mg}$ increased the PRA by $110 \%$. The change in day time systolic pressure with $100 \mathrm{mg}$ losartan $(-10.9 \pm 13.8 \mathrm{mmHg})$ was not significantly different from the changes seen with 75, 150 and $300 \mathrm{mg}$ aliskiren. All doses of aliskiren were well tolerated.

A multicenter 8-week trial randomized 1123 patients with mild to moderate hypertension ( $\mathrm{msDBP} \geq 95 \mathrm{mmHg}$ ) to once daily doses of aliskiren ( $75 \mathrm{mg}, 150 \mathrm{mg}$ or $300 \mathrm{mg}$ ), valsartan ( $80 \mathrm{mg}, 160 \mathrm{mg}$ or $320 \mathrm{mg}$ ), aliskiren/valsartan combinations (75/80 mg 150/160 mg or 300/320 mg), valsartan/HCTZ (160/12.5 mg) or placebo (Pool et al 2007). Compared with placebo, there were significant reductions in both msSBP and msDBP with aliskiren $300 \mathrm{mg}$ (10.0/8.6 vs 15.0/12.3 mmHg, $\mathrm{p}<0.001)$. Valsartan $160 \mathrm{mg}$ and $320 \mathrm{mg}$ doses lowered msSBP and msDBP significantly compared to aliskiren $150 \mathrm{mg}$ ( $\mathrm{p}<0.05$ for both valsartan doses) (Table 2). Placebo effect was prominent. A pooled analysis involving 8481 patients involved in double-blind trials with aliskiren and placebo arms for a period of 8 to 12 weeks revealed reductions in $\mathrm{msSBP} / \mathrm{msDBP}$ of $12.5 / 10.1$ and $15.2 / 11.8 \mathrm{mmHg}$ respectively from baseline with aliskiren 150 and $300 \mathrm{mg}$ doses compared to $6.2 / 5.9 \mathrm{mmHg}$ with placebo ( $\mathrm{p}<0.0001$ ) (Dahlof et al 2007). 


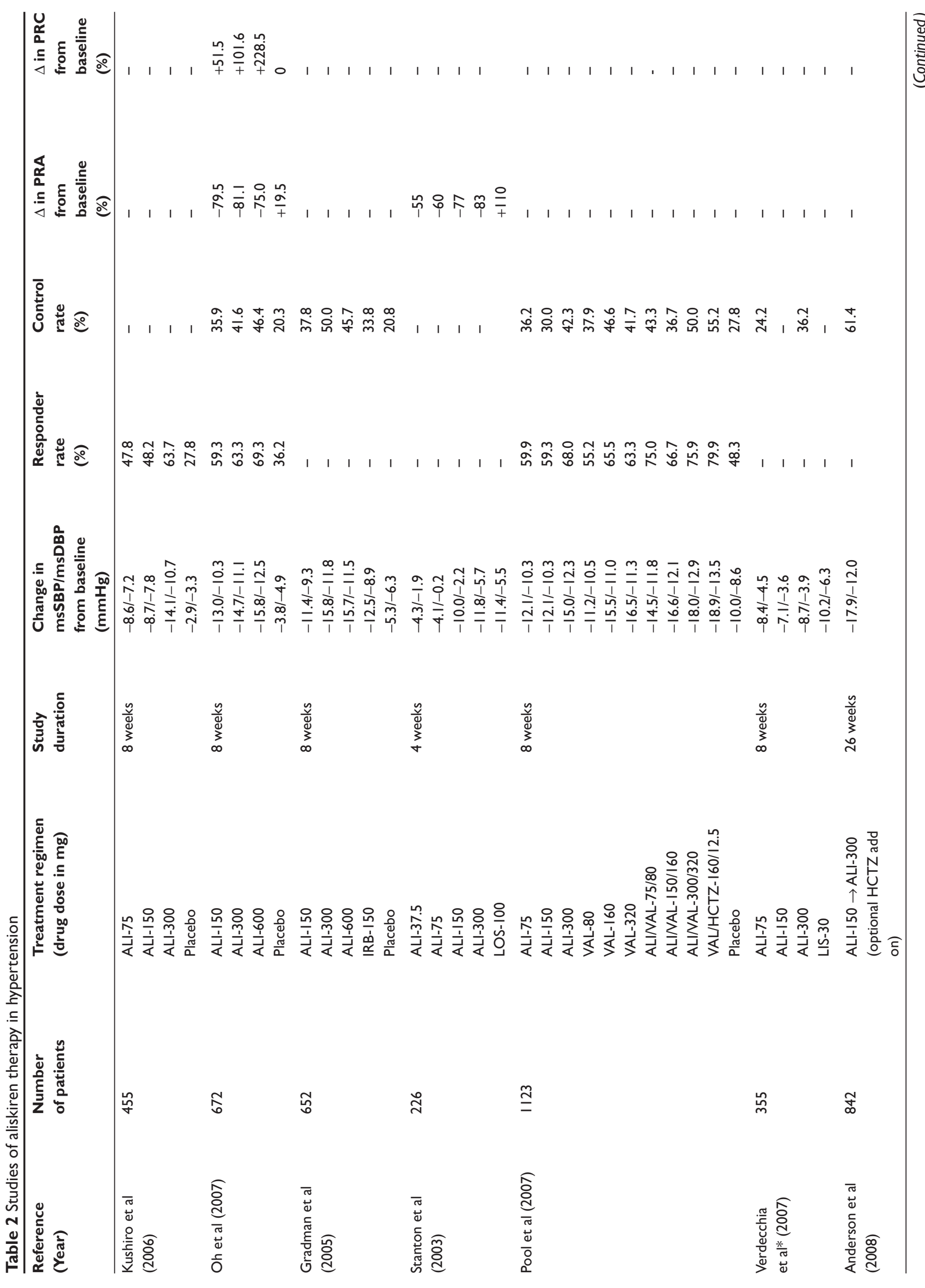




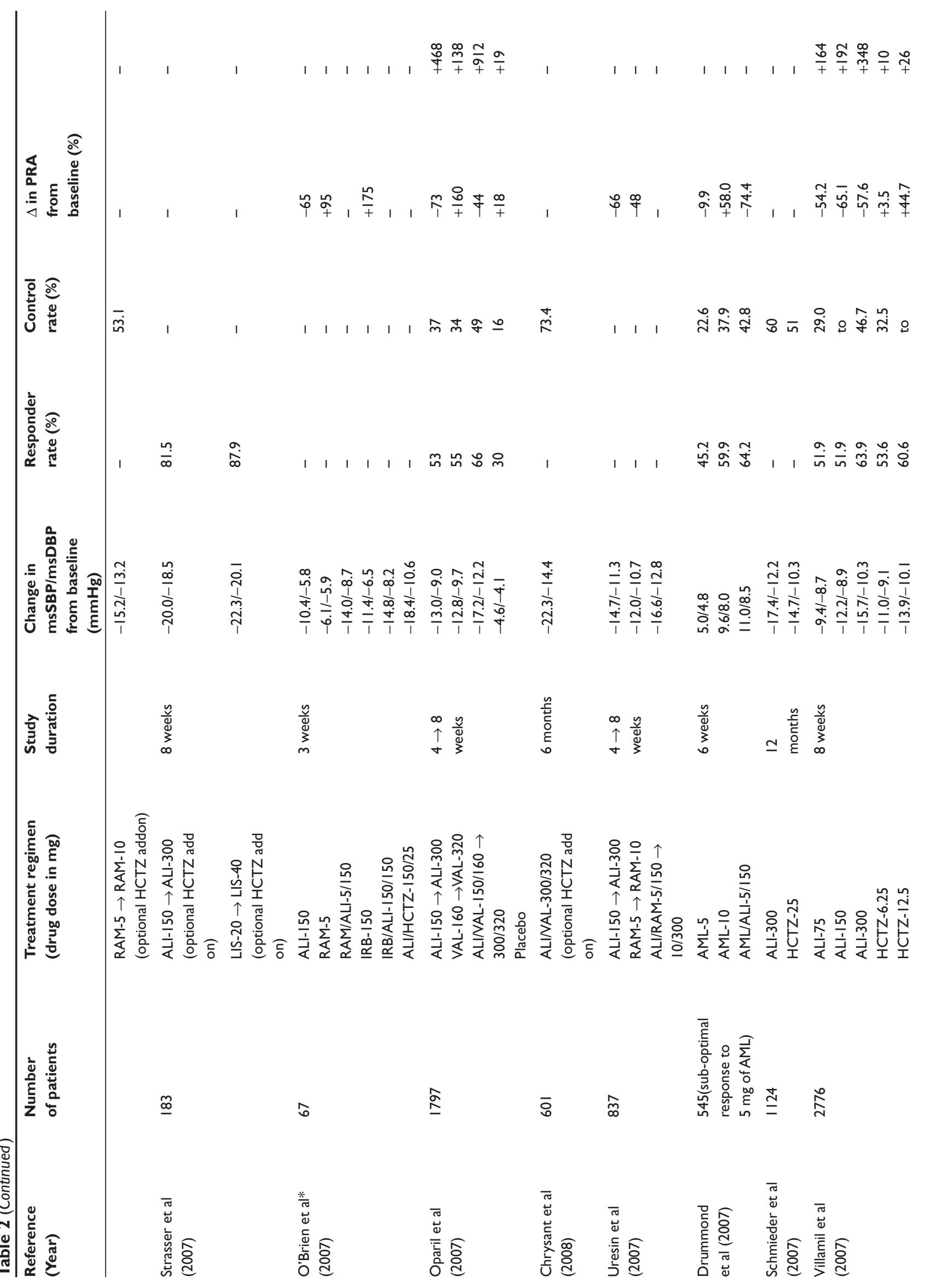




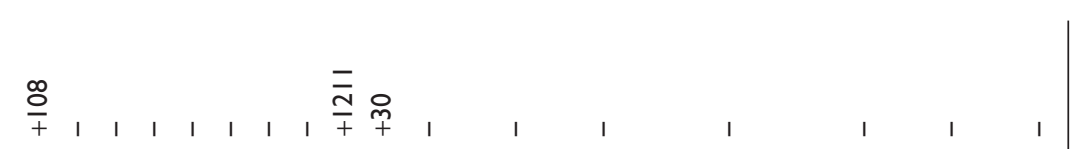

产䓬

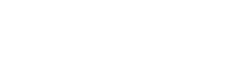

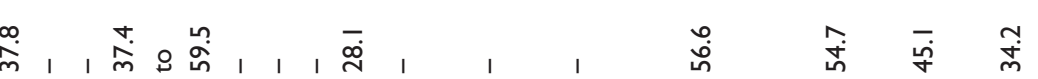

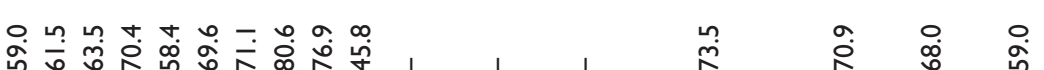

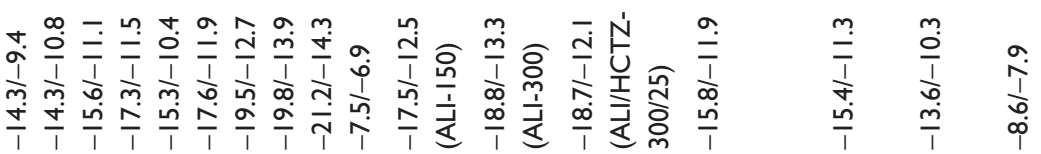
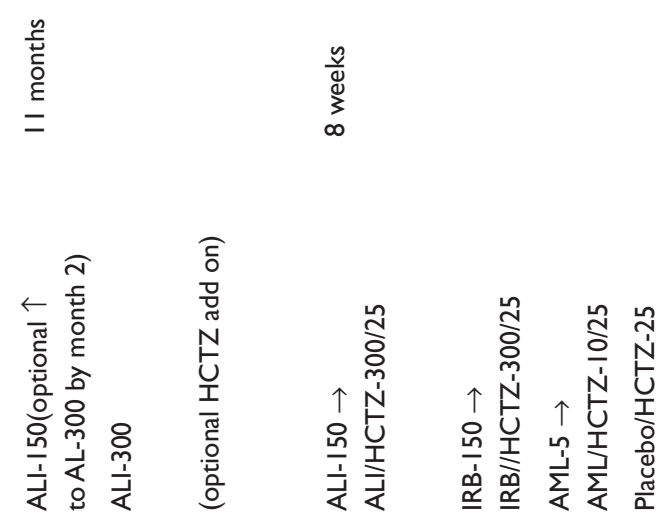

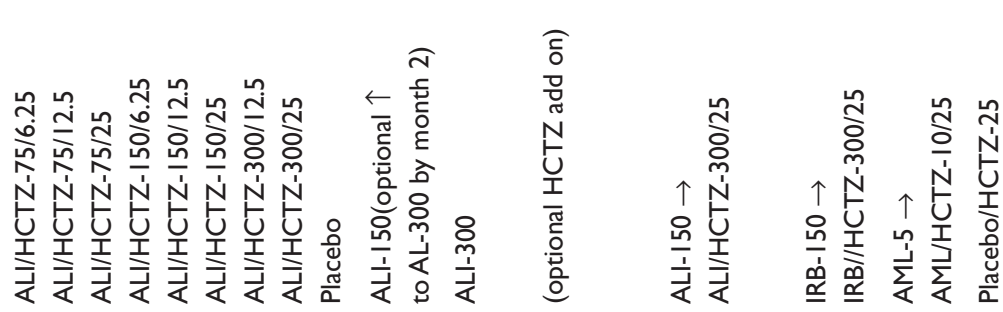
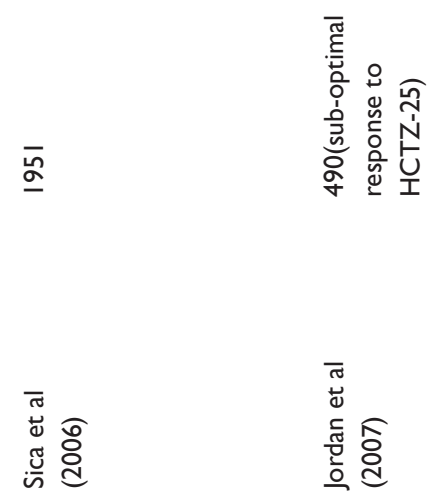

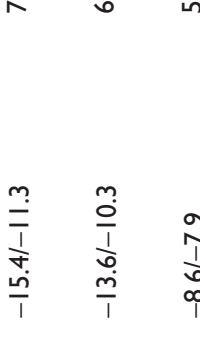

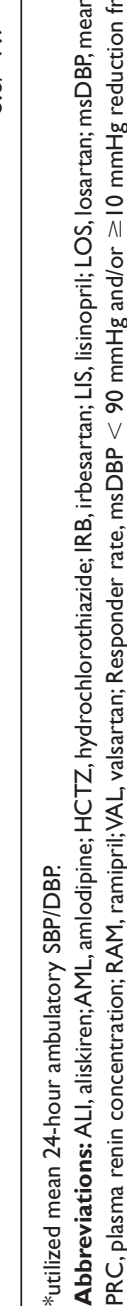


The efficacy, safety and tolerability of aliskiren were evaluated in patients $\geq 65$ years of age (Verdecchia et al 2007). In this study, 355 elderly patients with msSBP $145-179 \mathrm{mmHg}$ and mean 24-hour ambulatory SBP of $\geq 135 \mathrm{mmHg}$ underwent double-blind randomization to 8-week treatment with once daily aliskiren $(75,150$ or $300 \mathrm{mg}$ ) or lisinopril $10 \mathrm{mg}$. At study end, mean 24-hour ambulatory SBP/DBP decreased by $8.4 / 4.5,7.1 / 3.6,8.7 / 3.9$ and $10.2 / 6.3 \mathrm{mmHg}$ respectively with aliskiren 75, 150 and $300 \mathrm{mg}$ and lisinopril $10 \mathrm{mg}$ doses. A higher proportion of patients on aliskiren $300 \mathrm{mg}$ vs $75 \mathrm{mg}$ achieved BP $<140 / 90 \mathrm{mmHg}(36.2 \%$ vs $24.2 \%$, $\mathrm{p}=0.033$ ). All doses of aliskiren were well tolerated. Another study randomized 842 patients (msDBP $95-109 \mathrm{mmHg}$ ) to aliskiren $150 \mathrm{mg}$ or ramipril $5 \mathrm{mg}$ with subsequent doubling of the drug doses and addition of HCTZ (12.5-25 mg) for inadequate BP control (Andersen et al 2008). At 26-week follow-up, aliskiren-based therapy significantly lowered msSBP (17.9 vs $15.2 \mathrm{mmHg}, \mathrm{p}=0.0036)$, msDBP (13.2 vs $12.0 \mathrm{mmHg}, \mathrm{p}=0.025)$ and resulted in higher rates of BP control $(61.4 \%$ vs $53.0 \%, \mathrm{p}=0.0205)$ compared to ramipril based therapy. During drug withdrawal, BP increased more rapidly after stopping ramipril than aliskiren based therapy, median BP reached 140/90 mmHg after 1 and 4 weeks of drug withdrawal respectively. The incidence of serum potassium levels $>5.5 \mathrm{mmol} / \mathrm{L}$ was $1.9 \%$ in the aliskiren group and $1 \%$ in the ramipril group.

A double-blind multi-center 8-week trial randomized 183 patients with severe hypertension (msDBP $105-119 \mathrm{mmHg}$ ) in a 2:1 ratio, to aliskiren $150 \mathrm{mg}$ or lisinopril $20 \mathrm{mg}$ with dosedoubling and subsequent addition of HCTZ for additional BP control (Strasser et al 2007). Reductions in msSBP and msDBP as well as responder rates ( 81.55 vs $87.9 \%$ ) were similar between aliskiren and lisinopril groups (Table 2). Half of patients in each group needed HCTZ for adequate BP control.

In summary, monotherapy with aliskiren was well tolerated with antihypertensive effects comparable to losartan, irbesartan, lisinopril and ramipril. Dose-response curve seems to plateau at $300 \mathrm{mg}$ of aliskiren. Aliskiren consistently lowered PRA. Prominent placebo effects seen in most studies were attributed to factors such as regression to the mean, residual effects from previous therapy and limitations of cuff BP measurements.

\section{Aliskiren combination therapy in hypertension}

Antihypertensive efficacy, safety and tolerability of aliskiren in combination with HCTZ, ACE inhibitors, ARBs and calcium channel blockers were tested in patients with hypertension.

\section{Combination with an ACE inhibitor, ARB or calcium channel blocker}

Dual blockade of the RAAS can be achieved by utilizing combination of aliskiren with either an ACE inhibitor or an ARB. The additional antihypertensive effects of adding 6 weeks of aliskiren therapy $(75 \mathrm{mg}$ in the first 3 weeks and $150 \mathrm{mg}$ in the last 3 weeks) in patients with mild to moderate hypertension on monotherapy with ramipril $(n=21)$ or irbesartan $(n=23)$ was assessed in an open-label design using ambulatory blood pressure monitoring (ABPM) (O’Brien et al 2007). The addition of aliskiren to $5 \mathrm{mg}$ of ramipril further lowered both day time and night time BP compared to ramipril monotherapy while the addition of aliskiren to $150 \mathrm{mg}$ of irbesartan resulted in significant reduction in night time BP (Table 2). Ramipril and irbesartan monotherapy caused 90\% and $175 \%$ increase in PRA respectively. By contrast, when aliskiren was co-administered with ramipril or irbesartan, PRA levels were similar to or less than baseline values. Treatment compliance assessed from pill counts averaged $>95 \%$. The maximum individual serum potassium levels recorded when aliskiren was co-administered with ramipril or irbesartan were 5.3 and $5.5 \mathrm{mmol} / \mathrm{L}$ respectively.

A double-blind study randomized 1797 patients with hypertension (msDBP 95-109 mmHg and 8-hour daytime ambulatory diastolic $\mathrm{BP} \geq 90 \mathrm{mmHg}$ ) to receive once-daily aliskiren $150 \mathrm{mg}(\mathrm{n}=437)$, valsartan $160 \mathrm{mg}$ $(\mathrm{n}=455)$, a combination of aliskiren $150 \mathrm{mg}$ and valsar$\tan 160 \mathrm{mg}(\mathrm{n}=446)$, or placebo $(\mathrm{n}=459)$ for 4 weeks, followed by force titration to double the dose for another 4 weeks (Oparil et al 2007). Before the study end, $11 \%$ of patients discontinued treatment mainly due to lack of therapeutic effect. An intention-to-treat analysis at 8- week endpoint showed a significant reduction in $\mathrm{msSBP} / \mathrm{msDBP}$ from baseline with the combination of aliskiren and valsartan when compared to aliskiren $(\mathrm{p}<0.0001)$ or valsartan $(\mathrm{p}<0.0001)$ monotherapy or placebo $(\mathrm{p}<0.0001)$ (Table 2$)$. ABPM in a subset of patients also showed similar observation. Both aliskiren and valsartan monotherapy significantly decreased msSBP/msDBP compared to placebo ( $\mathrm{p}<0.0001)$. Combination therapy provide additional reductions of 4.2/3.2 mmHg over aliskiren monotherapy and 4.4/2.5 mmHg over valsartan monotherapy. PRC was highest in the combination therapy group (912\%) compared to patients who received aliskiren (468\%) or valsartan (138\%). While aliskiren $300 \mathrm{mg}$ monotherapy and aliskiren/valsartan combination therapy decreased PRA ( $73 \%$ and $44 \%$ respectively), valsartan $320 \mathrm{mg}$ monotherapy increased PRA by $160 \%$. A serum potassium of $>5.5 \mathrm{mmol} / \mathrm{L}$ was observed more frequently during 
combination therapy (4\%) than during aliskiren or valsartan monotherapy ( $2 \%$ each) or with placebo $(3 \%)$.

The 6-month interim analysis of a long-term, open-label study looking at the safety, tolerability and efficacy of aliskiren/valsartan 300/320-mg combination in patients with hypertension (msDBP 90-109 $\mathrm{mmHg}$ ) was reported recently (Chrysant et al 2008). A total of 601 patients received aliskiren/valsartan $(150 / 160 \mathrm{mg})$ combination for 2 weeks followed by forced titration to aliskiren/valsartan $300 / 320 \mathrm{mg}$ once daily for a targeted duration of 52 weeks. Optional HCTZ addition was allowed starting from week 8 if BP control was inadequate $(>140 / 90 \mathrm{mmHg})$. At the 6-month point, 512 patients were still ongoing with the study and 192 patients received at least once dose of HCTZ-add on therapy. Reductions in $\mathrm{msSBP} / \mathrm{msDBP}$ of 22.3/14.4 mmHg were observed at 6-month endpoint and $73.4 \%$ of patients achieved BP of $<140 / 90 \mathrm{mmHg}$. Ten patients $(2.5 \%)$ receiving aliskiren/valsartan and 2 patients (1\%) receiving aliskiren/valsartan/HCTZ developed serum potassium $>5.5 \mathrm{mmol} / \mathrm{L}$.

A double-blind multi-center trial, randomized 837 patients with diabetes mellitus and hypertension (msDBP 96-109 mmHg) to once daily aliskiren (150 mg, titrated to $300 \mathrm{mg}$ after 4 weeks; $\mathrm{n}=282$ ), ramipril ( $5 \mathrm{mg}$ titrated to $10 \mathrm{mg} ; \mathrm{n}=278$ ) or the combination for 8 weeks (Uresin et al 2007). When compared to ramipril or aliskiren monotherapy, aliskiren/ramipril combination provided superior reductions in $\operatorname{msDBP}(\mathrm{p}=0.004$ and 0.043 respectively) (Table 2 ). An additional reduction in mean BP of 4.6/2.1 mmHg was achieved by the addition of aliskiren to ramipril. PRC increased in all groups but there was a $66 \%$ reduction in PRA from baseline in the aliskiren group $(\mathrm{p}<0.0001)$ and a $48 \%$ reduction in the combination group $(\mathrm{p}<0.0001)$. The randomized trial by Pool et al discussed earlier noted similar reductions in $\mathrm{msSBP} / \mathrm{msDBP}$ with aliskiren/valsartan 150/160 mg and $300 / 320 \mathrm{mg}$ doses when compared to valsartan/HCTZ $160 / 12.5 \mathrm{mg}$ dose.

In a double-blind study, 545 patients whose msDBP remained at 90-109 $\mathrm{mmHg}$ despite 4 weeks of therapy with amlodipine $5 \mathrm{mg}$ daily were randomized to 3 arms for 6 weeks: continue amlodipine $5 \mathrm{mg}$, amlodipine $10 \mathrm{mg}$ or amlodipine $5 \mathrm{mg}$ with aliskiren $150 \mathrm{mg}$ (Drummond et al 2007). At study end, reduction in $\mathrm{msSBP} / \mathrm{msDBP}$ with aliskiren/ amlodipine 150/5 mg was significantly more compared to amlodipine $5 \mathrm{mg}$ monotherapy (11.0/8.5 vs $5.0 / 4.8 \mathrm{mmHg}, \mathrm{p}<0.001)$ but was similar to amlodipine $10 \mathrm{mg}$ monotherapy $(9.6 / 8.0 \mathrm{mmHg})$. Peripheral edema developed more frequently in the amlodipine $10 \mathrm{mg}$ group (11.2\%) compared to the combination therapy $(2.1 \%)$ and amlodipine $5 \mathrm{mg}(3.4 \%)$.

\section{Combination with HCTZ}

Antihypertensive efficacy of aliskiren has been studied both in comparison to and in combination with HCTZ. A 12-month randomized study compared the antihypertensive efficacy of once-daily doses of aliskiren $300 \mathrm{mg}$ and HCTZ $25 \mathrm{mg}$ in 1124 patients with mild to moderate hypertension (Schmieder et al 2007). Add on therapy with amlodipine 5 to $10 \mathrm{mg}$ was used as needed to achieve a target BP of 140/90 mmHg. Starting at 12 weeks, aliskiren $300 \mathrm{mg}$ significantly lowered BP from baseline compared to HCTZ (Table 2).

An 8-week multi-center double-blind trial randomized 2776 patients with msDBP of 95 to $109 \mathrm{mmHg}$ to different doses of aliskiren ( $75 \mathrm{mg}, 150 \mathrm{mg}$ or $300 \mathrm{mg}$ ), HCTZ (6.25 mg, $12.5 \mathrm{mg}$ or $25 \mathrm{mg}$ ), aliskiren/HCTZ combinations $(75 / 6.25,75 / 12.5,75 / 25,150 / 6.25,150 / 12.5,150 / 25$, $300 / 12.5,300 / 25 \mathrm{mg}$ ) or placebo (Villamil et al 2007). Aliskiren monotherapy with all 3 doses significantly lowered msDBP compared to placebo with a linear dose relationship $(\mathrm{p}=0.0002)$ (Table 2). HCTZ monotherapy with all 3 doses also significantly reduced msDBP compared to placebo but with a non-linear dose relationship ( $p<0.01$ ). All doses of HCTZ and aliskiren doses of 150 and $300 \mathrm{mg}$ significantly lowered msSBP compared to placebo. All combinations were superior to placebo $(\mathrm{p}<0.0001)$ and most were superior to both monotherapies $(\mathrm{p}<0.05)$ in lowering msDBP (exceptions were aliskiren/HCTZ 150/6.25 mg vs either monotherapy and aliskiren/HCTZ 75/12.5 mg vs HCTZ monotherapy). Reductions in msDBP from baseline to endpoint with combination therapy ranged from $10.4 \pm 0.59$ to $14.3 \pm 0.61 \mathrm{mmHg}$. All combinations were superior to component monotherapies in reducing msSBP from baseline $(\mathrm{p}<0.05)$, with the exception of aliskiren/HCTZ 75/12.5 mg vs HCTZ monotherapy. Reductions in msSBP from baseline to end point with combination therapy ranged from $14.3 \pm 0.93$ to $21.2 \pm 0.97 \mathrm{mmHg}$. Greatest reduction in BP was seen in patients on aliskiren/HCTZ $300 / 25 \mathrm{mg}$ (msSBP/ msDBP reduction of 21.5/14.3 $\mathrm{mmHg}$ ). Responder rate $(\mathrm{msDBP}<90 \mathrm{mmHg}$ and/or $\geq 10 \mathrm{mmHg}$ reduction from baseline) was $63.9 \%$ for aliskiren $300 \mathrm{mg}$ ( $\mathrm{p}=0.0005$ ), 60.6\% for HCTZ $12.5 \mathrm{mg}$ ( $\mathrm{p}<0.02$ ), 59.0\% for HCTZ $25 \mathrm{mg}(\mathrm{p}<0.02)$ and $58.4 \%$ to $80.6 \%$ for all combination doses (all p < 0.05 ) compared to $45.8 \%$ for placebo. Responder rates for all combinations of aliskiren $(75-300 \mathrm{mg}$ ) with HCTZ $25 \mathrm{mg}$ and aliskiren/HCTZ 300/12.5 mg 
were superior to both monotherapies $(\mathrm{p}<0.05)$, where as aliskiren/HCTZ 75/12.5 mg and 150/12.5 mg were superior to their respective aliskiren monotherapies $(\mathrm{p}<0.05)$. There was a trend towards higher control rare (defined as msSBP/ msDBP $<140 / 90 \mathrm{mmHg}$ at study end) with combination therapy $(37.4 \%-59.5 \%)$ when compared to either aliskiren (29.0\%-46.7\%) or HCTZ (32.5\%-37.7\%) monotherapies. Among the monotherapy groups, only aliskiren $300 \mathrm{mg}$ significantly improved control rate compared to placebo ( 46.7 vs $28.1 \%, p=0.0001$ ). Control rate were superior with all aliskiren/HCTZ combinations (except 75/6.25 mg group) when compared to placebo $(\mathrm{p}<0.02)$. The antihypertensive effects of aliskiren and HCTZ were comparable but it should be noted that the study was powered to compare the antihypertensive effects of the combination therapies with component monotherapies but not to compare the monotherapies with each other. PRA decreased by 54.2, 65.1 and $57.6 \%$ from baseline in patients taking aliskiren 75, 150 and $300 \mathrm{mg}$ doses where as PRA increased by 3.5, 44.7 and $71.9 \%$ with HCTZ doses of $6.25,12.5$ and $25 \mathrm{mg}$. A net reduction in PRA of $46.1 \%$ to $63.5 \%$ was observed in patients on aliskiren/HCTZ combinations. Placebo increased PRA only by $0.7 \%$ from baseline. PRC increased to a greater degree with aliskiren (164, 192 and 348\% with aliskiren 75, 150 and $300 \mathrm{mg}$ doses) compared to HCTZ (10, 26 and 108\% with HCTZ 6.25, 12.5 and $25 \mathrm{mg}$ doses). The highest PRC increase was seen with aliskiren/HCTZ $300 / 25 \mathrm{mg}$ combination (1211\% from baseline). Hypokalemia (serum potassium $<3.5 \mathrm{mmol} / \mathrm{L}$ ) developed in $3.9 \%$ and $5.9 \%$ of patients on HCTZ $12.5 \mathrm{mg}$ and $25 \mathrm{mg}$ doses respectively. The frequency of hypokalemia dropped to $0.7 \%$ to $2.0 \%$ and $2.2 \%$ to $3.4 \%$ respectively with drug combinations containing $12.5 \mathrm{mg}$ and $25 \mathrm{mg}$ HCTZ.

A 12-month open label study randomized patients with msDBP of 90-109 mmHg to aliskiren $150 \mathrm{mg}$ $(\mathrm{n}=1178)$ or $300 \mathrm{mg}(\mathrm{n}=773)$ once daily after washout and a 2-4 week drug-free period (Sica et al 2006). If BP remained $\geq 140 / 90 \mathrm{mmHg}$ after month 2 , doubling of aliskiren dose from 150 to $300 \mathrm{mg}$ or addition of HCTZ (12.5-25 mg) to aliskiren $300 \mathrm{mg}$ was permitted. A subgroup of patients remaining on aliskiren monotherapy at month 11 were randomized to continue aliskiren $(\mathrm{n}=132)$ or placebo $(\mathrm{n}=129)$ for 4 weeks as double-blind withdrawal phase. A total of 1625 (83\%) completed the study. Reductions in $\mathrm{msSBP} / \mathrm{msDBP}$ at the endpoint were 17.5/12.4 and 18.8/13.3 mmHg in aliskiren 150 and $300 \mathrm{mg}$ groups respectively. Addition of $\mathrm{HCTZ}$ was required in 868 patients $(45 \%)$ and BP reduction at the study end in this group $(18.7 / 12.1 \mathrm{mmHg})$ was comparable to aliskiren monotherapy group (17.4/13.3 $\mathrm{mmHg})$. During the withdrawal period, mean sitting BP gradually increased in the placebo group where as BP reduction was maintained in patients remaining on aliskiren with a statistically significant difference between the groups at the end of withdrawal period $(5.99 / 3.87 \mathrm{mmHg} \mathrm{p}=0.0001)$. This difference was also seen in a subgroup of patients who underwent ABPM (4.14/3.87 mmHg $\mathrm{p}<0.0001)$.

The additional antihypertensive benefit of aliskiren was analyzed in obese hypertensive (msDBP 95-109 mmHg) patients unresponsive to $25 \mathrm{mg}$ of HCTZ (Jordan et al 2007). After a 2- to 4-week washout period, 560 patients received single-blind HCTZ 25 mg for 4 weeks; 490 non-responders underwent double-blind randomization to aliskiren $150 \mathrm{mg}$, irbesartan $150 \mathrm{mg}$, amlodipine $5 \mathrm{mg}$ or placebo for 4 weeks while continuing HCTZ. This was followed by doubling the initial doses of aliskiren, irbesartan and amlodipine for 8 weeks. After 8 weeks of double-blind treatment (4 weeks on higher doses), BP reduction was significantly more with aliskiren/HCTZ compared to placebo/HCTZ (15.8/11.9 vs 8.6/7.9 mmHg, $\mathrm{p}<0.0001)$ and the significance persisted at study end ( $p<0.005$ for msDBP and $\mathrm{p}<0.0001$ for msSBP). $\mathrm{BP}$ reductions with irbesartan/HCTZ $(15.4 / 11.3 \mathrm{mmHg})$ and amlodipine/HCTZ (13.6/10.3 mmHg) were similar to aliskiren/ HCTZ (Table 2). The BP control rate (a BP $<140 / 90 \mathrm{mmHg}$ ) was significantly higher with aliskiren/HCTZ compared to placebo/HCTZ at week 8 end point $(\mathrm{p}=0.0005)$ and at week 12 end point ( $58.4 \%$ vs $33.3 \%, \mathrm{p}=0.0001$ ). The BP control rate among amlodipine/HCTZ and irbesartan/HCTZ were not significantly different from those observed with aliskiren/ HCTZ at week 8 and 12 end points but the BP control rate with aliskiren/HCTZ at week 8 end point was numerically higher compared to that observed with amlodipine/HCTZ (56.6 vs $45.1 \%, \mathrm{p}=0.052$ ). Compared with pretreatment baseline, PRA increased with HCTZ monotherapy $(\mathrm{p}<0.05)$ but when combined with aliskiren, there was a significant reduction in PRA ( $p<0.05)$. Combination of HCTZ with irbesartan and amlodipine resulted in further significant increase in PRA. The open-label study by O'Brien et al also looked at the benefits of adding $25 \mathrm{mg}$ of HCTZ $(\mathrm{n}=23)$ to $150 \mathrm{mg}$ of aliskiren daily for 3 weeks (O’Brien et al 2007). Compared to aliskiren monotherapy, there was significant reduction in day time BP with combination therapy (Table 2).

\section{Potential advantages of aliskiren/ HCTZ combination in hypertension}

Aliskiren monotherapy in large part demonstrated antihypertensive efficacy comparable to equivalent doses of HCTZ, losartan, irbesartan, lisinopril and ramipril. Fore effective BP 
control, majority of patients will require combination therapy. Both ACE inhibitors and ARBs are used extensively in combination with HCTZ. Aliskiren/HCTZ combination has several advantages. HCTZ has been clinically available for decades and costs less. It is considered the preferred first line antihypertensive agent in all comers (Chobanian et al 2003). While exerting its antihypertensive effects, HCTZ activates RAAS which can limit its efficacy. Agents blocking the RAAS such as aliskiren, ACE inhibitors and ARBs can augment the potency of HCTZ in addition to their own antihypertensive effects. At higher doses of aliskiren/HCTZ combination, reduction in BP was closer to the sum of BP reductions obtained with each monotherapy after excluding the placebo effects from all treatment groups. For instance, the placebo-corrected reduction in $\mathrm{msSBP} / \mathrm{msDBP}$ were 8.2/3.4, 6.9/2.5 and 13.7/7.4 $\mathrm{mmHg}$ respectively with aliskiren $300 \mathrm{mg}$, HCTZ $25 \mathrm{mg}$ and aliskiren/HCTZ 300/25 mg respectively in a large study (Villamil et al 2007). On the other hand, placebo-corrected reductions in $\mathrm{msSBP} / \mathrm{msDBP}$ with aliskiren $300 \mathrm{mg}$, valsartan $320 \mathrm{mg}$ and aliskiren/valsartan 300/320 mg were 5.0/3.7, 6.5/2.7 and $8.0 / 4.3 \mathrm{mmHg}$ respectively in one study (Pool et al 2007) and $8.4 / 4.9,8.2 / 5.2$ and $12.6 / 8.1 \mathrm{mmHg}$ respectively in another study (Oparil et al 2007).

In addition to its antihypertensive effects, HCTZ is also a week diuretic which helps to correct any underlying hypervolemia/sodium excess. Ability of aliskiren to lower angiotensin $_{1-7}\left(\mathrm{Ang}_{1-7}\right)$ levels may have a potential negative impact on BP lowering effects of aliskiren/ACE inhibitor and aliskiren/ARB combinations. Ang $_{1-7}$ is a heptapeptide fragment of Ang II that can buffer the vasoconstrictive and growth promoting effects of Ang II. Ang ${ }_{1-7}$ can block AT receptor and stimulate release of nitric oxide and vasodilating prostaglandins (Dellipizzi et al 1994; Mahon et al 1994; Freeman et al 1996; Li et al 1997). Both ACE inhibitors and ARBs increase the level of $\mathrm{Ang}_{1-7}$, the former by inhibiting the ACE-induced degradation of $\mathrm{Ang}_{1-7}$ and the latter by increasing Ang II level (substrate for $\mathrm{Ang}_{1-7}$ ) through $\mathrm{AT}_{1}$ receptor blockade. Elevated levels of $\mathrm{Ang}_{1-7}$ are thought to be contributing to the antihypertensive effects of both ACE inhibitors and ARBs (Luque et al 1996; Iyer et al 1998). Since direct renin inhibition can decrease $\mathrm{Ang}_{1-7}$ levels, it is intuitive to think that aliskiren might hamper antihypertensive effects of both ACE inhibitors and ARBs to some extent.

HCTZ monotherapy can cause hypokalemia and combination with aliskiren can mitigate this effect due to the potassium retaining effects of the latter. Dual inhibition of the RAAS can increase the risk of hyperkalemia. Fortunately hyperkalemia was not a frequent occurrence in studies of aliskiren combination therapy with ACE inhibitors and ARBs. The risk will be clearly increased in patients with underlying renal dysfunction.

\section{Safety and tolerability}

Aliskiren was well tolerated with adverse events and discontinuation rates similar to placebo in most clinical trials. An increased incidence of diarrhea was reported with $600 \mathrm{mg}$ dose of aliskiren. The adverse effects of aliskiren monotherapy were similar to placebo (39.8\% vs $40.2 \%)$ in a pooled analysis of over 2000 patients (Weir et al 2007). Most common adverse effects reported with aliskiren vs placebo were head ache (5.75 vs $8.7 \%$ ), nasopharyngitis $(4.4 \%$ vs $5.8 \%)$ and diarrhea $(2.6 \%$ vs $1.2 \%)$. Diarrhea was not associated with increased discontinuation rates. Serious adverse effects with aliskiren were low at $0.5 \%$ compared to $0.6 \%$ with placebo. Over $95 \%$ of the adverse effects were mild to moderate in severity thought to be unrelated to aliskiren.

Unlike ACE inhibitors, aliskiren does not affect the metabolism of bradykinin and substance P. Hence cough and angioedema are extremely rare with its use. Hyperkalemia is a concern when aliskiren is used in combination with ACE inhibitors or ARBs especially in patients with impaired renal function. Hypokalemia developed in 3.9 and $5.9 \%$ of patients who took 12.5 and $25 \mathrm{mg}$ HCTZ monotherapy which decreased to $0.7 \%-2.0 \%$ and $2.2 \%-3.4 \%$ respectively after the addition of aliskiren (Villamil et al 2007). Increased adverse effects may develop if aliskiren is used in volume depleted patients and those with severe renal artery stenosis. Aliskiren is contraindicated in pregnancy.

\section{Perspectives on direct renin inhibition with aliskiren}

RAAS plays a crucial role in chronic hypertension and end-organ damage. There is evidence that both ACE inhibitors and ARBs lower BP and confer end-organ protection in heart, kidney and blood vessels. Their efficacy is limited by redundant pathways in RAAS and counter regulatory mechanisms. Renin has been a therapeutic target for long time but a direct renin inhibitor has been available for clinical use only recently. Aliskiren may provide more complete and more effective blockade of RAAS. Cathepsin D and tonin pathways of Ang I generation are not blocked by renin inhibitors. But these pathways are not thought to be of significant physiological importance (Philips et al 1993). Compared to ACE inhibitors and ARBs, aliskiren 
induced more pronounced renal vasodilation in healthy normotensive human subjects (Fisher et al 2008). Studies thus far have shown similar antihypertensive effects at best with aliskiren when compared to equivalent doses of ACE- inhibitors, ARBs and diuretics. Aliskiren in combination therapies lowered BP more effectively than monotherapy and aliskiren/HCTZ combination appear to have more synergy. There is evidence from animal studies that aliskiren can confer end-organ protection in kidney and heart (Pilz et al 2005; Shagdarsuren et al 2005). Animal studies have also shown evidence for atherosclerotic plaque stabilization with aliskiren (Nussberger et al 2008). End organ protective effects of aliskiren in human studies are beginning to emerge. The recently published AVOID (Aliskiren in eValuation of prOteinuria in Diabetes) study has shown reduction in proteinuria independent of BP control in patients with diabetic nephropathy on background therapy with losartan $100 \mathrm{mg} /$ day (Parving et al 2008).

The recently discovered (pro)renin receptor can bind and activate both pro-renin and renin with consequent intracellular signaling of second messenger pathways through an Ang II independent mechanism. (Pro)renin receptor blockade has shown to confer end organ protection in animal studies (Takahashi et al 2007). Even though aliskiren could possibly modify pro-renin molecule and prevents its conversion to active renin, preliminary evidence indicate that aliskiren does not inhibit the renin-induced or pro-renin induced activation of the (pro)renin receptor (Schmieder 2007; Schefe et al 2008).

The reactive increase in $\mathrm{PRC}$ seen with aliskiren is more pronounced compared to other antihypertensive agents and is dose dependent. PRC increased even further with aliskiren/ HCTZ combination. It was suggested that the elevated PRC might be sufficient to overwhelm the renin inhibitory capacity of aliskiren and may even cause paradoxical elevation of $\mathrm{BP}$ in patients with hyperreactive RAAS such as those with renovascular and malignant hypertension (Sealey and Laragh 2007). Others have discounted this theory pointing to the properties of aliskiren including long half-life and lack of rebound hypertension after withdrawal (Menard and Azizi 2007). Another concern is the possibility that elevated PRC might cause harmful effects through the (pro)renin receptor. Available evidence indicate that aliskiren does not inhibit Ang II-independent intracellular signaling mediated through (pro)renin receptor but needs further clarification (Sarris et al 2006). Unlike other agents such as ACE inhibitors, ARBs and diuretics, aliskiren consistently decreased PRA as monotherapy and in combination therapy. Pretreatment
PRA has shown a direct association with cardiovascular risk in hypertensive patients (Aldeman et al 1997). However, no study has yet reported such an association with drug induced elevations in PRA.

\section{Conclusions}

Aliskiren is the first direct renin inhibitor available for clinical use. The long half-life and absence of rebound phenomenon makes aliskiren suitable for once daily administration. Favorable side-effect profiles and high trough-to peak ratios are other features of aliskiren. The antihypertensive efficacy of monotherapy with aliskiren is dose-dependent up to $300 \mathrm{mg}$ daily doses and is comparable to ACE inhibitors such as lisinopril and ramipril, ARBs such as losartan and irbesartan as well as HCTZ. Combination therapy with ACE inhibitors, ARBs, amlodipine and HCTZ were also well tolerated. Because of the complimentary pharmacological action of aliskiren and HCTZ, their combination seems favorable in hypertension. Aliskiren 150 to $300 \mathrm{mg}$ with HCTZ 12.5 to $25 \mathrm{mg}$ are the most effective of these single daily combinations. Since reactive increase in PRC could be a potential limiting factor with aliskiren in terms of its antihypertensive efficacy and beta blockers can blunt this response, combining aliskiren with a beta blocker looks attractive. Such a study using aliskiren-atenolol combination was completed recently and results are awaited. One has to be cautious about the risk of hyperkalemia with strategies utilizing dual blockade of RAAS. Studies are underway looking at the long-term efficacy, safety and tolerability of combination therapy of aliskiren with HCTZ or with agents blocking RAAS. In addition, outcome studies looking at the beneficial effects of aliskiren on left ventricular mass in obese hypertensive patients as well as its effect on post-myocardial infarction LV remodeling are ongoing.

\section{Disclosures}

The author has no conflicts of interest to disclose.

\section{References}

Aldeman MH, Ooi WI, Cohen H, et al. 1997. Plasma renin activity: a risk factor for myocardial infarction in hypertensive patients. Am J hypertens, 10:1-18.

Andersen K, Weinberger MH, Egan B, et al. 2008. Comparative efficacy and safety of aliskiren, an oral direct renin inhibitor, and ramipril in hypertension: a 6-month, randomized, double-blind trial. J Hypertens, 26:589-99.

Azizi M, Menrad J, Bissery A, et al. 2004. Pharmacologic demonstration of the synergistic effects of a combination of the renin inhibitor aliskiren and the AT1-receptor antagonist valsartan on the angiotensin II-renin feedback interruption. J Am Soc Nephrol, 15:3126-33.

Azizi M, Webb R, Nussberger J, et al. 2006. Renin inhibition with aliskiren: where are we now and where are we going? J Hypertens, 24:243-56. 
Azizi M, Menrad J, Bissery A, et al. 2007. Hormonal and hemodynamic effects of aliskiren and valsartan and their combination in sodiumreplete normotensive individuals. Clin J Am Soc Nephrol, 2:947-55.

Chiarelli F, Pomilio M, De Luca FA, et al. 2001. Plasma prorenin levels may predict persistent microalbuminuria in children with diabetes. Pediatr Nephrol, 16:116-20.

Chobanian AV, Bakris GL, Black HR, et al. 2003. Seventh report of the Joint National Committee on Prevention, Detection, Evaluation and Treatment of High Blood Pressure. Hypertension, 42:1206-52.

Chrysant SG, Murray AV, Hoppe UC, et al. 2008. Long-term safety, tolerability and efficacy of aliskiren in combination with valsartan in patients with hypertension: a 6-month interim analysis. Curr Med Res Opin, 24:1039-47.

Cushman WC, Ford CE, Cutler JA, et al. 2002. Success and predictors of blood pressure control in diverse North American settings: The Antihypertensive and Lipid Lowering Treatment to Prevent Heart Attack Trial (ALLHAT). J Clin Hyertens, 4:393-404.

Dahlof B, Anderson DR, Arora V, et al. 2007. Aliskiren, a direct renin inhibitor, provides antihypertensive efficacy and excellent tolerability independent of age or gender in patients with hypertension. $J$ Clin Hypertens, 9 (Suppl A):A157.

Danser AH, Derkx FH, Schalekamp MA, et al. 1998. Determinant so finterindividual variation of renin and pro-renin concentrations evidence for a sexual dimorphism of (pro)renin levels in humans. $J$ Hypertens, 16:853-62.

Danser AHJ, Deinum J. 2005. Renin, pro-renin and the putative (pro)renin receptor. Hypertension, 46:1069-76.

Dellipizzi AM, Hilchey SD, Bell-Quilley CP. 1994. Natriuretic action of angiotensin (1-7). Br J Pharmacol, 111:1-3.

Dieterle W, Corynen S, Mann J. 2004. Effect of the oral renin inhibitor aliskiren on the pharmacokinetics and pharmacodynamics of a single dose of warfarin in health subjects. $\mathrm{Br} J$ Clin Pharmacol, 58:433-6.

Dieterich H, Kemp C, Vaidyanathan S, et al. 2006. Aliskiren, the first in a new class of orally effective renin inhibitors, has no clinically significant interactions with digoxin in healthy volunteers. Clin Pharmacol Ther, 79:111-24.

Dieterle W, Corynen S, Vaidyanathan S, et al. 2005. Pharmacokinetic interactions of the oral renin inhibitor aliskiren with lovastatin, atenolol, celecoxib and cimetidine. Int J Clin Pharmacol Ther, 43:527-35.

Drummond W, Munger MA, Essop MR, et al. 2007. Antihypertensive efficacy of the oral direct renin inhibitor aliskiren as add-on therapy in patients not responding to amlodipine monotherapy. J Clin Hypertens, 9:742-50.

Dzau VJ. 2001. Tissue angiotensin and pathophysiology of vascuklar disease, a unifying hypothesis. Hypertension, 37:1047-52.

Feldman DL, Jin L, Xuan H, et al. 2008. Effect of aliskiren on blood pressure, albuminuria, and(pro)renin receptor expression in diabetic $\mathrm{TG}(\mathrm{mRen}-2)$ rats. Hypertension, 52:130-6.

Fisher ND, Hollenberg NK. 2001. Is there a future for renin inhibitors? Exp Opin Invest Drugs, 10:417-26.

Fisher ND, Jan Danser AH, Nussberger J, et al. 2008. Renal and hormonal responses to direct renin inhibition with aliskiren in healthy humans. Circulation, 117:3199-205.

Freeman EJ, Chisolm GM, Ferrario CM, et al. 1996. Angiotensin (1-7) inhibits vascular smooth muscle growth. Hypertension, 28:104-8.

Ganten D, Wagner J, Zeh K et al. 1992. Species specificity of renin kinetics in transgenic rats harboring the human renin and angiotensin genes. Proc Natl Acad Sci U S A, 89:7806-10.

Gradman AH, Schmieder RE, Lins RL, et al. 2005. Aliksiren, a novel orally effective renin inhibitir, provides dose-dependent antihypertensive efficacy and placebo-like tolerability in hypertensive patients. Circulation, 111:102-8.

Hollenberg NK, Fisher ND, Price DA. 1998. Pathways of angiotensin II generation in intact human tissue: Evidence from comparative pharmacological interruption of the renin system. Hypertension, 32:387-92.
Iyer SN, Chappell MC, Averill DB, et al. 1998. Vasodepressor actions of angiotensin (1-7) unmasked during combine treatment with lisinopril and losartan. Hypertension, 31:699-705.

Jordan J, Engeli S, Boye SW, et al. 2007. Direct renin inhibition with aliskiren in obese patients with arterial hypertension. Hypertension, 49:1047-55

Kearney PM, Whelton M, Reynolds K, et al. 2005. Global burden of hypertension: analysis of worldwide data. Lancet, 365:217-23.

Kelly DJ, Zhang Y, Moe G, et al. 2007. Aliskiren, a novel renin inhibitor, is renoprotective in a model of advanced diabetic nephropathy in rats Diabetologia, 50:2398-404.

Kim S, Iwao H. 2000. Molecular and cellular mechanisms of angiotensin II-mediated cardiovascular and renal diseases. Pharmacol Rev, 52:11-34.

Kushiro T, Itakura H, Abo Y, et al. 2006. Aliskiren, a novel oral renin inhibitor, provides dose-dependent efficacy and placebo-like tolerability in Japanese patients with hypertension. Hypertens Res, 29:997-1005.

Li P, Chappell MC, Ferrario CM, et al. 1997. Angiotensin (1-7) augments bradykinin-induced vasodilation by competing with $\mathrm{ACE}$ and releasing nitric oxide. Hypertension, 29:394-400.

Luetscher JA, Kraemer FB, Wilson DM, et al. 1985. Increased plasma inactive renin in diabetes mellitus a marker of microvascular complications. N Engl J Med, 312:1412-17.

Luque M, Martin P, Martell N, et al. 1996. Effects of captopril related to increased levels of prostacyclin and angiotensin-(1-7) in essential hypertension. J Hypertens, 14:799-805.

Mahon JM, Carr RD, Nicol AK, et al. 1994. Angiotensin (1-7) is an antagonist at the type 1 angiotensin II receptor. J Hypertens, 12:1377-81.

Materson BJ, Reda DJ, Cushman WC, et al. 1993. Single drug therapy for hypertension in men. A comparison of six antihypertensive agents with placebo. The department of Veterans Affairs Cooperative Study Group on Antihypertensive agents. $N$ Engl J Med, 328:914-21.

Menard J, Aziz M. 2007. The difficult conception, birth and delivery of renin inhibitor: controversies around aliskiren. J Hypertens, 25:1775-82.

Novartis Pharmaceuticals Corporation. 2007. Tecturna ${ }^{\circledR}$ (aliskiren tablets): US prescribing information. East Hanover, NJ.

Nguyen G, Delarue F, Burckle C, et al. 2002. Pivotal role of the renin/ pro-renin receptor in angiotensin II production and cellular responses to renin. J Clin Invest, 109:1417-27.

Nussbeger J,Wuerzner G, Jensen C, et al. 2002. Angiotensin II suppression in humans by the orally active renin inhibitor aliskiren (SPP100); Comparison with enalapril. Hypertension, 39:E1-8.

Nussberger J, Aubert JF, Bouzourene K, et al. 2008. Renin inhibition by aliskiren prevents atherosclerosis progression: comparison with irbesartan, atenolol, and amlodipine. Hypertension, 51:1306-11.

O'Brien E, Barton J, Nussberger J, et al. 2007. Aliskiren reduced blood pressure and suppress plasma renin activity in combination with a thiazide diuretic, an angiotensin converting enzyme inhibitor, or an angiotensin receptor blocker. Hypertension, 49:276-84.

Oh BH, Mitchell J, Herron JR, et al. 2007. Aliskiren, an oral renin inhibitor, provides dose-dependent efficacy and sustained 24-hour blood pressure control in patients with hypertension. $J$ Am Coll Cardiol, 49:1157-63.

Ong KL, Cheung BM, Man YB, et al. 2007. Prevalence, awareness, treatment and control of hypertension among United States adults 1999-2004. Hypertension, 49:69-75.

Oparil S, Haber E.1974. The renin angiotensin system. $N$ Engl J Med, 291:381-401.

Oparil S, Yarows SA, Patel S, et al. 2007. Efficacy and safety of combined use of aliskiren and valsartan in patients with hypertension: a randomized, double-blind trial. Lancet, 370:221-9.

Parving HH, Persson F, Lewis JB, et al. 2008. Aliskiren combined with losartan in type 2 diabetes and nephropathy. $N$ Engl J Med, 358:2433-46.

Philips MI, Speakman EA, Kimura B. 1993. Levels of angiotensin and molecular biology of the tissue angiotensin systems. Regul Pept, 43:1-20. 
Pilz B, Shagdarsuren E, Wellner M, et al. 2005. Aliskiren, a human renin inhibitor, ameliorates cardiac and renal damage in double-transgenic rats. Hypertension, 46:569-76.

Pool JL, Schmieder RE, Azizi M, et al. 2007. Aliskiren, an orally effective renin inhibitor, provides antihypertensive efficacy alone and in combination with valsartan. Am J Hypertens, 20:11-20.

Sarris JJ, 't Hoen PAC, Garrelds IM, et al. 2006. Pro-renin induces intracellular signaling in cardiomyocytes independently of angiotensin II. Hypertension, 48:564-71.

Shagdarsuren E, Wellner M, Braesen JH, et al. 2005. Compliment activation in angiotensin II induced organdamge. Circ Res, 97:716-24.

Schefe JH, Neumann C, Goebel M, et al. 2008. Prorenin engages the (pro)renin receptor like renin and both ligand activities are unopposed by aliskiren. J Hypertens, 26:1787-94.

Schmieder RE. 2007. The potential role of pro-renin in diabetic nephropathy. J Hypertens, 25:1323-6.

Schmieder RE, Philipp T, Guerediaga J, et al. 2007. Aliskiren-based therapy lowers blood pressure more effectively than hydrochlorothiazidebased therapy in patients with hypertension. J Clin Hypertens, 9(Suppl A):A182.

Sealey JE, Laragh JH. 2007. Aliskiren, the first renin inhibitor for treating hypertension: reactive renin secretion may limit its effectiveness. $\mathrm{Am}$ J Hypertens, 20:587-97.

Sica D, Gradman A, Lederballe O, et al. 2006. Aliskiren, a novel renin inhibitor, is well tolerated and has sustained BP-lowering effects alone or in combination with HCTZ during long-term (52 weeks) treatment of hypertension. Eur Heart J, 27(Suppl):A797.

Siragy HM, Xue C, Abadir P, et al. 2005. Angiotensin subtype-2 receptors inhibit renin biosynthesis and angiotensin II formation. Hypertension, 45:133-7.

Skolnik NS, Beck JD, Clark M. 2000. Combination antihypertensive drugs: recommendations for use. Am Fam Physician, 61:3049-56.

Smithies O.1997. Theodore Cooper Memorial Lecture. A mouse view of hypertension. Hypertension, 30:1318-24.

Stanton A, Jensen C, Nussberger J, O’Brien E.2003. Blood pressure lowering in essential hypertension with an oral renin inhibitor, aliskiren. Hypertension, 42:1137-43.

Strasser RH, Puig JG, Farsang C, et al. 2007. A comparison of the tolerability of the direct renin inhibitor aliskiren and lisinopril in patients with severe hypertension. J Hum Hypertens, 21:780-7.

Takahashi H, Ichihara A, Kaneshiro Y, et al. 2007. Regression of nephropathy developed in diabetes by (pro)renin receptor blockade. J Am Soc Nephrol, 18:1989-92.
Urata H, Kinoshita A, Misono KS, et al. 1990. Identification of a highly specific chymase as the major angiotensin II forming enzyme in the human heart. J Biol Chem, 265:22348-57.

Uresin Y, Taylor AA, Kilo C, et al. 2007. Efficacy and safety of the direct renin inhibitor aliskiren and ramipril alone or in combination in patients with diabetes and hypertension. J Renin Angiotensin Aldosterone Syst, 8:190-8.

Vaidyanathan S, Velencia J, Kemp C, et al. 2006. Lack of pharmacokinetic interactions of aliskiren, a novel direct renin inhibitor for the treatment of hypertension, with the antihypertensives amlodipine, valsartan, hydrochlorothiazide (HCTZ) and ramipril in healthy volunteers. Int J Clin Pract, 60:1343-56.

Vaidyanathan S, Reynolds C, Yeh CM, et al. 2007. Pharmacokinetics, safety and tolerability of the novel oral direct renin inhibitor aliskiren in elderly healthy subjects. J Clin Pharmacol, 47:453-60.

Verdecchia P, Calvo C, Mockel V, et al. 2007. Safety and efficacy of the oral direct renin inhibitor aliskiren in elderly patients with hypertension. Blood Press, 16:381-91.

Villamil A, Chrysant SG, Calhoun D, et al. 2007. Renin inhibition with aliskiren provides additive antihypertensive efficacy when used in combination with hydrochlorothiazide. J Hypertens, 25:217-26.

Waeber B. 2003. Combination therapy with ACE inhibitors/angiotensin II receptor antagonists and diuretic in hypertension. Expert Rev Cardiovascular Ther, 1: 43-50.

Waldmeier FJ, Glaenzel U, Wirz B, et al. 2007. Absorption, distribution, metabolism and elimination of the direct renin inhibitor aliskiren in healthy volunteers. Drug Metab Dispos, 35:1418-28.

Wantanabe T, Barker TA, Berk BC. 2005. Angiotensin II and the endothelium: diverse signals and effects. Hypertension, 45:163-9.

Weir MR, Bush C, Anderson DR, et al. 2007. Antihypertensive efficacy, safety, and tolrability of the oral direct renin inhibitor aliskiren in patients with hypertension: a pooled analysis. J Am Soc Hypertens, 1:264-77.

Williams B. 2001. Angiotensin II and the pathophysiology of cardiovascular remodeling. Am J Cardiol, 87:10C-17C.

Whaley-Connell A, Habibi J, Cooper SA, et al. 2008. Effect of renin inhibition and AT1R blockade on myocardial remodeling in the transgenic Ren2 rat. Am J Physiol Endocrinol Metab, (Epub ahead of print).

Wolf-Maier K, Cooper RS, Kramer H, et al. 2004. Hypertension treatment and control in five European countries, Canada and the United States. Hypertension, 43:10-7.

Wood JM, Mailbaum J, Rahuel J, et al. 2003. Structure based design of aliskiren, a novel orally effective renin inhibitor. Biochem Biophys Res Commun, 308:698-705 